УДК 351.74:343.627

DOI https://doi.org/10.32849/2663-5313/2019.10.26

\title{
Павло Біленко,
}

фахівещь відділу організащії служби

Донещького юридичного інституту Міністерства внутрішніх справ Украӥни

\section{УПОВНОВАЖЕНІ ОРГАНИ НАЦІОНАЛЬНОЇ ПОЛІЦІЇ УКРАЇНИ ЯК СУБ'ЄКТИ ЗАПОБІГАННЯ ТА ПРОТИДІЇ ДОМАШНЬОМУ НАСИЛЬСТВУ}

У статті розглянуті повноваження уповноважених органів Національної поліиії України як суб'єкта запобігання та протидії домашньому насильству. На підставі аналізу існуючих підходів до поняття суб'єкта протидії злочинності відзначено, що за своєю суттю иі визначення є подібними, оскільки відзначають структуру даних органів, напрями та межі їх повноважень. Відзначено, що запобігати домашньому насильству покликано багато інститутів держави та громадськості, до яких відносяться: 1) спечіально уповноважені органи у сфері запобігання та протидіі домашньому насильству; 2) інші органи та установи, на які покладаютьься функиії зі здійснення заходів у сфері запобігання та протидії домашнвому насильству; 3) загальні та спещіалізовані служби підтримки постраждалих осіб; 4) громадяни України, іноземиі та особи без громадянства, які перебувають в Україні на законних підставах

Розглянуто загальні повноваження уповноважених підрозділів Начіональної поліиії України як іншого органу та установи, на які покладаються функиї зі здійснення заходів у сфері запобігання та протидії домашньому насильству. Здійснено аналіз відомчих нормативно-правових актів Міністерства внутрішніх справ Украйни, що визначають адміністративно-правовий статус підрозділів Національної поліиії України, та встановлено, що спещіальні повноваження у сфері запобігання та протидіі домаиньому насильству мають Департамент превентивної діяльності Національної поліиії України, патрульна служба МВС України, підрозділи ювенальної превениії, служба дільничних офічерів полічії.

На підставі аналізу повноважень уповноважених підрозділів Національної полічії України, які здійснюють запобігання та протидію домашньому насильству, слід констатувати, що основним суб'єктом у сфері запобігання та протидї̈ омашньому насильству є служба дільничних офіцерів поліиії, оскільки більшість повноважень, які визначено у ст. 10 Закону України від 07.12.2017 № 2229-VIII «Про запобігання та протидію домашньому насильству», віднесена до їхньої компетениї. Запропоновано закріпити вичерпний перелік уповноважених підрозділів Національної поліції України, які здійснюють запобігання та протидію домашньому насильству, у згаданому Законі.

Ключові слова: запобігання злочинності, протидія злочинності, домашнє насильство, суб'єкти протидії злочинності, Національна поліція України.

Постановка проблеми. Відповідно до Угоди про асоціацію між Україною, з однієі сторони, та Європейським Союзом, Європейським Співтовариством з атомної енергії і їхніми державами - членами, з іншої сторони, наша держава зобов'язалась поступово наближати своє законодавство до законодавства Свропейського Союзу щодо дотримання гендерної рівності, зокрема для забезпечення рівних можливостей для жінок та чоловіків у працевлаштуванні, освіті, професійній підготовці, економіці та суспільстві тощо.

У листопаді 2011 року Україна підписала Конвенцію Ради Свропи про боротьбу 3 насильством щодо жінок та домашнім насильством, що зобов'язує уряди країн, які іï підписали, вжити конкретних заходів для боротьби з усіма формами насильства щодо жінок - від примушування до шлюбу і сек- суальних домагань до побиття та каліцтва жіночих геніталій.

Вже протягом тривалого часу однією 3 гострих проблем для України залишається домашнє насильство. На жаль, не існує об'єктивної та достовірної інформації про масштаби цього соціального явища, оскільки в більшості випадків воно залишається латентним. Офіційна статистика не засвідчує реального стану домашнього насильства через те, що більшість постраждалих не звертаються за допомогою до підрозділів Національної поліції України.

Прийняття 7 грудня 2017 року Закону України «Про запобігання та протидію домашньому насильству» стало новим вектором реалізації державної політики у сфері запобігання та протидії домашньому насильству.

Запобігати цьому соціальному негативному явищу покликані багато державних 
та громадських інститутів, особливе місце серед яких займають уповноважені підрозділи Національної поліції України. Тому визначення повноважень уповноважених органів Національної поліції України у сфері запобігання та протидії домашньому насильству має основоположне значення.

Метою статті є дослідити нормативно-правове регулювання й повноваження уповноважених органів Національної поліції України у сфері запобігання та протидії домашньому насильству.

Виклад основного матеріалу. Загальноприйнятою є точка зору, відповідно до якої злочинність є явищем, притаманним будь-якому суспільству. Такий підхід зумовив розроблення наукових концепцій запобігання й протидії злочинності в цілому, і окремим іï видам зокрема, а також формулювання на цій підставі кримінологічної політики в цій сфері.

Говорячи про кримінологічну політику у сфері запобігання та протидії злочинності взагалі, слід відзначити, що вона ніколи не має на меті ліквідувати злочинність як явище в житті суспільства, а навпаки, ставить реальні завдання щодо зниження її рівня, встановлення за нею соціального контролю для того, щоб злочинність не стала реальною загрозою для держави й окремих громадян. I таку політику визначають суб'єкти протидії злочинності.

О. Литвинов та Є. Гладкова відзначають, що суб'єкт протидії злочинності - це корпоративне утворення, організація галузевого масштабу. Таке визначення корпорації може бути застосовано до окремого суб'єкта в тому плані, що вони самі є об'єднанням первинних ділових організацій: департаментів, управлінь, служб і безлічі допоміжних підрозділів. Правоохоронні корпорації не лише розвивають унікальні напрямки протидії злочинності, а й виходять у цій діяльності далеко за межі своїх функцій, розвиваючи власну мережеву структуру із гнучкими лінійними зв'язками [1, с. 94]. Існує і точка зору, згідно з якою система суб'єктів протидії злочинності є складною соціальною організацією, що об'єднує безліч різноманітних складових частин. У свою чергу, групи однорідних органів, що входять до неї, утворюють відносно самостійні організаційні формування, які функціонують на основі тотожних закономірностей. Кожен із суб'єктів має складну структуру, у свою чергу утворюючи ієрархічно організовану систему зі своїми елементами. На рівні побудови суспільної формації сукупність суб'єктів протидії злочинності як автоном- ний елемент входить у структуру організаційного компоненту протидії злочинності та її механізму [2].

Наведені нами визначення суб'єктів протидії злочинності дозволяють зробити висновок, що за своєю суттю ці визначення є подібними, оскільки відзначають структуру цих органів, напрями та межі їх повноважень.

У протидії злочинності беруть участь представницькі органи, органи виконавчої влади, судові органи; весь комплекс підприємств, установ і організацій, що функціонують у різних сферах соціальної життєдіяльності; громадські об'єднання та окремі громадяни. Але діяльність переважної частини таких органів здійснюється у процесі розв'язання інших завдань. Лише невелика частина цих суб'єктів, які реалізують спеціальні цілі й обов'язки із впливу на ті або інші криміногенні фактори, здійснюють відповідне інформаційне, методичне, ресурсне, кадрове забезпечення, а їхня діяльність є спеціально обумовленою. Не виключенням є і Національна поліція України, яка є центральним органом виконавчої влади, який служить суспільству шляхом забезпечення охорони прав і свобод людини, протидії злочинності, підтримання публічної безпеки і порядку [3].

Відповідно до Закону України від 07.12.2017 № 2227-VIII «Про внесення змін до Кримінального та Кримінального процесуального кодексів із метою реалізації положень Конвенції Ради Свропи про запобігання насильству стосовно жінок і домашньому насильству та боротьбу із цими явищами» КК України було доповнено ст. 126-1 «Домашне насильство» (набула чинності 11 січня 2019 р.), під яким розуміється умисне систематичне вчинення фізичного, психологічного або економічного насильства щодо подружжя чи колишнього подружжя або іншої особи, з якою винний перебуває (перебував) у сімейних або близьких відносинах, що призводять до фізичних або психологічних страждань, розладів здоров'я, втрати працездатності, емоційної залежності або погіршення якості життя потерпілої особи. Можна погодитися з В. Голіною, що криміналізація домашнього насильства підтверджує курс кримінального права на реалізацію завдання правового забезпечення запобігання злочинам у сфері насильства в сім'ї (ст. 1 КК) [4, с. 40].

У ч. 1 ст. 6 Закону України від 07.12.2017 № 2229-VIII «Про запобігання та протидію домашньому насильству» (далі - Закон) визначено перелік суб'єктів, що здійснюють заходи у сфері запобігання та протидії домашньому насильству, до яких відносяться: 
1) спеціально уповноважені органи у сфері запобігання та протидії домашньому насильству;

2) інші органи та установи, на які покладаються функції зі здійснення заходів у сфері запобігання та протидії домашньому насильству;

3) загальні та спеціалізовані служби підтримки постраждалих осіб;

4) громадяни України, іноземці та особи без громадянства, які перебувають в Україні на законних підставах [5].

Що ж стосується інших органів та установ, на які покладаються функції зі здійснення заходів у сфері запобігання та протидії домашньому насильству, то до них відповідно до Закону відносяться й уповноважені підрозділи органів Національної поліції України.

Стаття 10 Закону визначає повноваження уповноважених підрозділів Національної поліції України, до яких віднесено:

1) виявлення фактів домашнього насильства та своєчасне реагування на них;

2) прийом і розгляд заяв та повідомлень про вчинення домашнього насильства, в тому числі розгляд повідомлень, що надійшли до кол-центру з питань запобігання та протидії домашньому насильству, насильству за ознакою статі та насильству стосовно дітей, вжиття заходів для його припинення та надання допомоги постраждалим особам з урахуванням результатів оцінки ризиків у порядку, визначеному центральним органом виконавчої влади, що забезпечує формування державної політики у сфері запобігання та протидії домашньому насильству, спільно з Національною поліцією України;

3) інформування постраждалих осіб про їхні права, заходи і соціальні послуги, якими вони можуть скористатися;

4) винесення термінових заборонних приписів стосовно кривдників;

$5)$ взяття на профілактичний облік кривдників та проведення з ними профілактичної роботи в порядку, визначеному законодавством;

6) здійснення контролю за виконанням кривдниками спеціальних заходів протидії домашньому насильству протягом строку їхньої дії;

7) анулювання дозволів на право придбання, зберігання, носіння зброї та боєприпасів їхнім власникам у разі вчинення ними домашнього насильства, а також вилучення зброї та боєприпасів у порядку, визначеному законодавством;

8) взаємодія з іншими суб'єктами, що здійснюють заходи у сфері запобігання та протидії домашньому насильству;
9) звітування центральному органу виконавчої влади, що реалізує державну політику у сфері запобігання та протидії домашньому насильству, про результати здійснення повноважень у цій сфері в порядку, визначеному центральним органом виконавчої влади, що забезпечує формування державної політики у сфері запобігання та протидії домашньому насильству [5].

Таким чином, діяльність уповноважених підрозділів Національної поліції займає ключове місце в питанні протидії домашньому насильству, адже саме на дану інституцію покладено обов'язок безпосередньо здійснювати комплекс попереджувальних (профілактичних) і припинювальних заходів. Проте у ст. 10 Закону окреслено загальне коло повноважень, але не конкретизовано, на які саме підрозділи органів Національної поліції України покладено повноваження щодо запобігання та протидії домашньому насильству.

Проведений нами аналіз нормативноправових актів, зокрема Закону України від 02.07.2015 № 580-VIII «Про Національну поліцію», Закону України від 07.12.2017 № 2229-VIII «Про запобігання та протидію домашньому насильству», постанови Кабінет Міністрів України від 22.08.2019 № 658 «Про затвердження Порядку взаємодії суб'єктів, що здійснюють заходи у сфері запобігання та протидії домашньому насильству i насильству за ознакою статі», наказу МВС України від 01.08.2018 № 654 «Про затвердження Порядку внесення уповноваженими підрозділами органів Національної поліції України термінового заборонного припису стосовно кривдника» дозволяє зробити висновок про відсутність чіткого переліку уповноважених підрозділів органів Національної поліції України, які вживають заходів для запобігання та протидії домашньому насильству.

Виходячи із повноважень, які визначені у відомчих нормативно-правових актах Міністерства внутрішніх справ України, що визначають адміністративно-правовий статус підрозділів Національної поліції України, до уповноважених підрозділів Національної поліції України, які здійснюють запобігання та протидії домашньому насильству, можна віднести: Департамент превентивної діяльності Національної поліції України; патрульну службу МВС України; підрозділи ювенальної превенції; службу дільничних офіцерів поліції.

Зокрема, відповідно до положення про Департамент превентивної діяльності Національної поліції України, затвердженого наказом МВС України від 27.11.2015 № 123, 
Департамент серед іншого: уживає заходів iз запобігання та припинення насильства в сім'ї; здійснює розроблення проектів законів та інших нормативних актів і документів, що стосуються забезпечення діяльності 3 питань підтримання публічної безпеки й порядку, забезпечення безпеки дорожнього руху, охорони прав і свобод людини, інтересів суспільства й держави, протидії злочинності, організації роботи дозвільної системи, запобігання та припинення насильства в сім'ї, превентивної та профілактичної діяльності; здійснює індивідуально-превентивну роботу з особами, які перебувають на профілактичних обліках у підпорядкованих підрозділах, насамперед з особами, звільненими 3 місць позбавлення волі, та тими, які вчиняють насильство в сім'ї (домашне насильство) [6, с. 191]

У п. 6 розділу $\mathrm{V}$ «Організація роботи діяльності дільничних офіцерів поліції (далі - ДОП) з особами, які перебувають на превентивному обліку» Інструкції з організації діяльності дільничних офіцерів поліції (затверджена наказом МВС України від 28.07.2017 № 650) зазначено: «ДОП виявляє на поліцейській дільниці осіб, які вчиняють насильство в сім'ї (домашнє насильство) або схильні до такої поведінки, та вживає превентивних заходів, передбачених законодавством і спрямованих на запобігання правопорушенням, пов'язаним із насильством у сім'ї, відповідно до норм Закону України «Про попередження насильства в сім'і» [7].

Наказом МBC України від 23.06.2015 № 742 «Про затвердження Положення про Департамент патрульної служби Міністерства внутрішніх справ» регламентовано, що до основних завдань патрульної служби також віднесено запобігання кримінальним, адміністративним правопорушенням; попередження, виявлення та припинення кримінальних та адміністративних правопорушень, випадків насильства у сім'ї, а також виявлення причин $і$ умов, що сприяють їх учиненню (виділ. - П.Б.) [8].

У наказі МВС України від 19.12.2017 № 1044 «Про затвердження Інструкції з організації роботи підрозділів ювенальної превенції Національної поліції України» зазначено, що до основних завдань і повноважень підрозділів ювенальної превенції Національної поліції України віднесено: вжиття заходів щодо запобігання та протидії домашньому насильству, вчиненому дітьми та стосовно них, а також жорстокому поводженню з дітьми (завдання); інформування відповідних місцевих органів державної влади щодо батьків, інших законних представників, які не виконують обов'язки щодо виховання дітей, жорстоко 3 ними поводяться чи вчиняють стосовно дітей домашне насильств (повноваження) [9].

\section{Висновки}

Підсумовуючи вищевикладене, можна зробити такі висновки:

1. До уповноважених підрозділів Національної поліції України, які здійснюють запобігання та протидії домашньому насильству, відносяться Департамент превентивної діяльності Національної поліції України; патрульна служба МВС України; підрозділи ювенальної превенції; служба дільничних офіцерів поліції.

2. Аналіз повноважень уповноважених підрозділів Національної поліції України, які здійснюють запобігання та протидію домашньому насильству, дозволяє констатувати, що основним суб'єктом у сфері запобігання та протидії домашньому насильству є служба дільничних офіцерів поліції, оскільки більшість повноважень, які визначено у ст. 10 Закону України від 07.12.2017 № 2229-VIII «Про запобігання та протидію домашньому насильству», віднесена до їх компетенції.

3. Вважаємо вкрай необхідним внести доповнення до Закону України від 07.12.2017 № 2229-VIII «Про запобігання та протидію домашньому насильству», закріпивши в ньому вичерпний перелік уповноважених підрозділів Національної поліції України, які здійснюють запобігання та протидії домашньому насильству.

Удосконалення нормативно-правових актів підвищить ефективність заходів із протидії цьому соціальному негативному явищу, та дозволить, на нашу думку, більш ефективно протидіяти домашньому насильству в українському суспільстві.

\section{Список використаних джерел:}

1. Литвинов О.М., Гладкова Є.О. Суб’єкти протидії злочинності як правоохоронні корпорації. Вісник Кримінологічної асоціації України. 2019. № 1(20). C. 90-98.

2. Суб'єкти протидії злочинності. URL : https://visnikkau.webnode.com.ua/news/ sub-jekti-protidiji-zlochinnosti/ (дата звернення: 01.10.2019).

3. Про Національну поліцію : Закон України від 02.07.2015 № 580-VIII. URL : https://zakon. rada.gov.ua/laws/show/580-19/print (дата звернення: 01.10.2019).

4. Голіна В.В. Запобігання та протидія домашньому насильству: стан i перспективи його подолання в Україні. Організачійно-правові засади запобігання домашньому насильству: реалії та перспективи: матеріали круглого столу, 
31 травня 2019 р. / за ред. О.П. Рябчинської. Запоріжжя : КПУ, 2019. С.40-43.

5. Про запобігання та протидію домашньому насильству : Закон України від 07.12.2017 № 2229-VIII. URL : https://zakon. rada.gov.ua/laws/show/2229-19 (дата звернення: 01.10.2019).

6. Дідик Н.І. Превентивні функції діяльності патрульної поліції. Вісник Луганського державного університету внутрішніх справ імені Е.О. Дідоренка. 2016. № 2. С. 188-194.

7. Про затвердження Інструкції з організації діяльності дільничних офіцерів поліції наказ MBC України від 28.07.2017 № 650. URL : https:/ / zakon.rada.gov.ua/laws / show / z1041-17 (дата звернення: 01.10.2019).

8. Про затвердження Положення про Департамент патрульної служби Міністерства внутрішніх справ : наказ МВС України від 23.06.2015 № 742. URL : https://zakon.rada.gov.ua/ laws/show/z1041-17 (дата звернення: 01.10.2019).

9. Про затвердження Інструкції з організації роботи підрозділів ювенальної превенції Національної поліції України: наказ МВС України від 1912.2017 № 1077. URL : https://zakon.rada.gov.ua/ laws/show/z0686-18 (дата звернення: 01.10.2019).

This article is concerning on empowerments of National Police of Ukraine authorized units as subjects of domestic violence prevention and counteraction. Relying on current approaches to definition of crime counteraction subject it has been established that by nature these terms are similar because they are defining these units' structure, fields of activity and limits of power. It has been stressed that many state and social institutes aimed at domestic violence prevention including: 1) specially authorized bodies of power in the field of domestic violence prevention and counteraction; 2) other bodies and offices that are assigned to put into effect measures in the field of domestic violence prevention and counteraction; 3) general and specialized services of victims support; 4) citizens of Ukraine, foreigners and stateless persons who are lawfully staying in Ukraine.

General empowerments of National Police of Ukraine authorized units as other body and office that is assigned to put into effect measures in the field of domestic violence prevention and counteraction have been studied. An analysis of Ministry of Internal Affairs of Ukraine regulatory acts that are defined an administrative legal status of National Police of Ukraine units has been made; it was found that Department of Prevention Activity of National Police of Ukraine, MIA of Ukraine Patrol Service, Juvenile Prevention units and Local Police Officers Service have been assigned special powers in the field of domestic violence prevention and counteraction.

Relying on study of empowerments of National Police of Ukraine authorized units in the field of domestic violence prevention and counteraction it is possible to conclude that Local Police Officers Service is the main subject in the abovementioned field since majority of powers stipulated by Art. 10 of Law of Ukraine "On Domestic Violence Prevention and Counteraction" dated from December 7th, 2017, № 2229-VIII have been attributed to its competence and tasks. It has been offered to amend the Law of Ukraine "On Domestic Violence Prevention and Counteraction” dated from December 7 th, 2017, № 2229-VIII by supplementation and preservation of exhaustive list of National Police of Ukraine authorized units in the field of domestic violence prevention and counteraction.

Key words: crime prevention, crime counteraction, domestic violence, subjects of crime counteraction, National Police of Ukraine. 